\title{
A LINGUAGEM FOTOGRÁFICA NO ENSINO FUNDAMENTAL II EM GEOGRAFIA: UMA SEQUÊNCIA DIDÁTICA PARA O ESTUDO DA CIDADE
}

\section{THE PHOTOGRAPHIC LANGUAGE IN ELEMENTARY EDUCATION II IN GEOGRAPHY: A DIDACTIC SEQUENCE FOR THE STUDY OF THE CITY}

\author{
EL LENGUAJE FOTOGRÁFICO EM EDUCACIÓN PRIMARIA II EN \\ GEOGRAFÍA: UNA SECUENCIA DIDÁCTICA PARA EL ESTUDIO DE LA \\ CIUDAD
}

\author{
Devid Hallyson da Silva Nascimento ${ }^{1}$ https://orcid.org/0000-0001-8591-9435 \\ Pablo Sebastian Moreira Fernandez ${ }^{2}$ https://orcid.org/0000-0002-5594-6990
}

\begin{abstract}
${ }^{1}$ Licenciado e Mestre em Geografia - UFRN. Professor de Geografia da rede privada de ensino. Email: teacherdevid@gmail.com

${ }^{2}$ Doutor em Geografia - UFG. Professor do Centro de Educação - Departamento de Práticas Educacionais e Currículo e dos Programa de Pós-graduação em Geografia - Mestrado Profissional (GEOPROF) e PPGEO - Universidade Federal do Rio Grande do Norte. E-mail: pablosmfernandez@gmail.com
\end{abstract}

\section{RESUMO}

Este artigo é derivado de uma dissertação e de um produto educativo que considera a Fotografia como uma linguagem para o ensino/aprendizagem da temática cidade no Ensino Fundamental II em Geografia. Tal proposta se dá a partir de uma reflexão inicial sobre os usos de "fotografias didáticas" na sala de aula e no livro didático tendo como foco a temática cidade. Deste modo, propôs-se utilizar a experiência dos sujeitos escolares, que habitam a cidade de Macaíba/RN, potencializando a partir de uma proposta pedagógica, a criação de narrativas fotográficas que versam sobre o cotidiano e lugares de vivência de jovens estudantes. $\mathrm{O}$ estudo realizado propôs a articulação do Ensino de Geografia com a área das Linguagens (em especial as imagéticas), estabelecendo um diálogo permanente entre a fotografia mobile com o método fenomenológico, em busca por acessar a ideia de geograficidade e experiência espacial. Autores como Ítalo Calvino (1972), James Hillman (1993), Cazetta e Oliveira (2013), Callai (2005), Cavalcanti (2002; 2013) Dantas (2011), Dardel (2011), Fernandez (2008; 2013), Larrosa (2017) e ainda o filósofo Roland Barthes (1984), possibilitaram delimitar os caminhos que fundamentam o percurso da pesquisa e da elaboração do produto didático a ser experimentado de modo a incentivar e compreender as experiências espaciais na cidade. A Sequência Didática, produto desta pesquisa, articula o conteúdo cidade com uma proposta de investigação caminhante e fotografante, a ser tomada pelo professor de Geografia como uma "reapropriação" das ruas e espaços de uma cidade, como potente objeto do conhecimento em suas práticas docentes. 
Palavras-chave: Ensino de Geografia. Fotografia. Cidade. Metodologia. Prática de Ensino.

\begin{abstract}
This article is derived from a dissertation and an educational product that considers Photography as a language for teaching/learning the city theme in Elementary School II in Geography. This proposal is based on an initial reflection on the uses of "didactic photographs" in the classroom and in the textbook, focusing on the city theme. In this way, it was proposed to use the experience of school subjects, who inhabit the city of Macaíba/RN, enhancing, from a pedagogical proposal, the creation of photographic narratives that deal with the daily life and places of experience of young students. The study carried out proposed the articulation of Geography Teaching with the area of Languages (especially imagery), establishing a permanent dialogue between mobile photography and the phenomenological method, seeking to access the idea of geographicality and spatial experience. Authors such as Ítalo Calvino (1972), James Hillman (1993), Cazetta and Oliveira (2013), Callai (2005), Cavalcanti (2002; 2013) Dantas (2011), Dardel (2011), Fernandez (2008; 2013), Larrosa (2017) and even the philosopher Roland Barthes (1984), made it possible to delimit the paths that underlie the path of research and the elaboration of the didactic product to be experimented in order to encourage and understand the spatial experiences in the city. The Didactic Sequence, the product of this research, articulates the city content with a walking and photographing research proposal, to be taken by the Geography teacher as a "reappropriation" of the streets and spaces of a city, as a powerful object of knowledge in their teaching practices.
\end{abstract}

Keywords: Geographical Education. Photograph. City. Methodology. Teaching Practice.

\title{
RESUMEN
}

Este artículo se deriva de una disertación y de un producto educativo que considera la fotografía como un lenguaje para la enseñanza/aprendizaje del tema ciudad en la Escuela Primaria II en Geografía. Esta propuesta parte de una reflexión inicial sobre los usos de "fotografías didácticas" en el aula y en el libro didáctico, centrándose en la temática ciudad. De esta forma, se propuso utilizar la experiencia de los sujetos escolares, que habitan la ciudad de Macaíba/RN, potenciando, desde una propuesta pedagógica, la creación de narrativas fotográficas que aborden la vida cotidiana y los lugares de vivencia de los jóvenes estudiantes. El estudio realizado propuso la articulación de la Enseñanza de la Geografía con el área de los lenguajes (especialmente los visuales), estableciendo un diálogo permanente entre la fotografía móvil y el método fenomenológico, buscando acceder a la idea de geografía y experiencia espacial. Autores como Ítalo Calvino (1972), James Hillman (1993), Cazetta y Oliveira (2013), Callai (2005), Cavalcanti (2002; 2013) Dantas (2011), Dardel (2011), Fernandez (2008; 2013), Larrosa (2017) e incluso el filósofo Roland Barthes (1984), permitieron delimitar los caminos que fundamentan la dirección de la investigación y la elaboración del producto didáctico a experimentar para incentivar y comprender las experiencias espaciales en la ciudad. La Secuencia Didáctica, producto de esta investigación, articula el contenido ciudad con una propuesta de investigación caminando y fotografiando, para ser tomada por el maestro de Geografía como una "reapropiación" de las calles y 
espacios de una ciudad, como un poderoso objeto de conocimiento en sus prácticas de enseñanza.

Palabras clave: Enseñanza de la geografía, Fotografía, Ciudad, Metodología, Practica Docente.

\section{INTRODUÇÃO}

Este texto se estrutura em duas etapas, a primeira referente ao campo conceitual e outra empírica, precisamente baseada em uma prática educativa de Geografia escolar. Conceitualmente buscou-se criar um "alicerce teórico" que nos permitisse garantir uma reflexão (que fosse instigante) acerca da linguagem fotográfica como expressão narrativa e de seu uso enquanto parte de estratégias educativas em aulas de Geografia no Ensino Fundamental II. No campo empírico, o pesquisador se coloca enquanto um professor que caminha, fotografa, descobre e explora a cidade (esta, objeto do conhecimento de sua prática); permitindo-se enquanto sujeito ao reconhecimento de seus espaços vividos e suas nuances por intermédio da fotografia mobile, por detrás das lentes, porém partícipe do ambiente, entendendo que ao mesmo tempo em que se coloca a fotografar, ele participa produzindo o espaço, lugares, paisagens.

Este artigo é parte de uma pesquisa de mestrado $^{3}$ que considerou a Fotografia como protagonista no âmbito de uma prática de ensino/aprendizagem de Geografia em três dimensões: 1) enquanto recorte material do espaço e assim, como texto a ser apreendido pelo raciocínio geográfico; 2) como linguagem potente para a narração de experiências geográficas; e 3) como recurso didático-pedagógico no campo da Geografia. A primeira dimensão associa-se à compreensão da Fotografia como um texto, uma linguagem a ser interpretada e entendida como recorte espaço-temporal (DANTAS, 2011); a segunda dimensão liga-se a interpretação da Fotografia enquanto grafia do espaço, uma linguagem a expressar experiências com a cidade, através do caminhar e do enquadramento de paisagens, em uma estrutura narrativa (HILLMAN, 1993; FERNANDEZ, 2008).

Já a terceira dimensão, considera a Fotografia enquanto forma e caminho pedagógico, a ser incorporada no cotidiano escolar por meio de seus sujeitos, como caminho para a compreensão de conceitos, teorias, metodologias e para a formação de um olhar que conduza a compreensão de singularidades, identidades, fluxos e formas espaço-temporais que se apresentam além sala de aula: no bairro, na rua, na cidade, e em outras escalas de 
análise. De modo geral, a Fotografia é um texto que diz algo, que revela e carrega intenções, o que no contexto educativo, possibilitaria observar, enxergar, ver, compreender, falar, escrever, experienciar, sentir... e nos mostra que "o mundo se revela em formatos, cores, atmosferas, texturas - uma exposição de formas que se auto-apresentam" (HILLMAN, 1993, p.14).

Assim, durante a realização da pesquisa, a Fotografia se consolidou como uma "linguagem de experimentação" da cidade (e do espaço urbano), visto que as linguagens tecem uma epistemologia no âmbito da ciência geográfica e participam da construção de uma educação espacial contemporânea, entendendo-as "como potencialmente fundadoras de outras geografias e percursos curriculares" (CAZETTA e OLIVEIRA JR., 2013, p. 13). Essa mesma linguagem que desenha sentidos os traz ao porto, desperta experiências, cria (recria) e possibilita práticas educativas que se convertem, no final, em aprendizagem.

É a partir da Fotografia que esboçamos uma pedagogia da cidade, que abarcasse uma estratégia para ensinar Geografia enquanto linguagem múltipla, que aproximasse o caminhar (e outras formas de mobilidade) enquanto possibilidade cartográfica, imersiva em um determinado recorte espacial e temporal, elegendo o espaço citadino como laboratório para a criação de narrativas fotográficas, de modo reflexivo, crítico e dinâmico (FERNANDEZ, 2008; SILVA, 2021). Mas por que estudar a cidade?

Partiremos do pressuposto que a cidade carrega em si uma "face" educativa, que implicaria possibilidades de atuação sobre ela, visto que é um lugar cotidiano a "nossos" alunos, aonde se relacionam, caminham e produzem um conjunto de espacialidades, que as vezes "passam desapercebidas". Esta ideia de cidade, nos mobilizou e fomentou a criação de práticas educativas que utilizassem a linguagem fotográfica como suporte para elaboração e criação de um conhecimento acerca da temática, agora considerada um espaço de aprendizagem. Tal compreensão foi aprofundada a partir de autores que consideram a cidade como um campo de experimentação, tendo entre estes, na literatura, Ítalo Calvino (1972), na psicologia Hillman (1993), na Geografia, Cazetta e Oliveira (2013), Cavalcanti (2002; 2013), Dantas (2011), Dardel (2011) e Fernandez (2008; 2013) e, na Educação, Neta (2016).

A partir deste arcabouço teórico e conceitual sobre cidade e Fotografia, vislumbrouse a criação de uma Sequência Didática como produto educativo desenvolvido em uma turma do Ensino Fundamental II na cidade de Macaíba-RN. Tal momento prático se iniciou 
com a realização de uma pesquisa ${ }^{1}$ com 22 professores do Ensino Básico, buscando identificar seus os usos da Fotografia dentro do ambiente da sala de aula e seu papel no livro didático. Essa exploração inicial permitiu à pesquisa, o diálogo com "sequências" presentes em livros didáticos tratando do conteúdo cidade a partir da Fotografia. Um primeiro entendimento é que estas seriam tratadas em sua maioria como ilustração de conceitos, o que induziria a um "modo homogêneo" de se trabalhar as "paisagens urbanas", inquietação que orientaria uma proposição que fosse pautada na experiência de sujeitos e seus lugares.

Assim, a Sequência Didática busca valorizar uma geograficidade das cidades, em diálogo com Eric Dardel, para quem "a cidade, como realidade geográfica, é a rua" e entendendo essa rua como o "centro e quadro da vida cotidiana, onde o homem é passante, habitante, artesão; elemento constitutivo e permanente" (DARDEL, 2011, p. 28) desse lugar. Uma cidade e um homem que, ao mesmo tempo, são metamorfose e ambulante, que se entreolham, se misturam, mas, em si, guardam suas essências que, ao passo que se deixam misturar, tornam-se tão indissociáveis que nos leva a indicar que homem e cidade são uma coisa só.

\section{A FOTOGRAFIA, A GEOGRAFIA E A CIDADE}

Basta apertar um botão, e pronto! Temos uma fotografia.

É fato que, desde o surgimento das primeiras câmeras fotográficas, "congelar" o tempo tornou-se fetiche de muita gente, em especial da burguesia moderna, no início do século XIX, símbolo de sua autoafirmação social e econômica. Todavia, com a popularização das câmeras fotográficas, já no início do século XX, fotografar tornou-se acessível, um passatempo. Nossos avós e pais, mais recentemente, nos juntavam para olhar os álbuns preenchidos de fotografias de aniversários, festas tradicionais, momentos importantes como a primeira eucaristia, a formação no Fundamental I, fotos de viagens e diversos outros registros (SONTAG, 2004).

Está aí uma das potências da Fotografia: dar suporte a nossos traços de memória, sua capacidade de revelar momentos somente repetíveis pelo auxílio das lembranças, nos permitindo reviver o que aconteceu. Como nos diz Roland Barthes (1984, p. 13), "o que a fotografia reproduz ao infinito só ocorre uma vez: ela repete mecanicamente o que nunca mais poderá repetir-se existencialmente". O tempo é o oxigênio e/ou combustível que

\footnotetext{
${ }^{1}$ Foi realizada a aplicação de um questionário on-line (via Formulário do Google) com 22 professores de Geografia (da Região Metropolitana de Natal) entre os meses de agosto e setembro de 2020 no contexto da pesquisa, de modo a compreender o uso da fotografia em sala de aula e no livro didático.
} 
estimula a memória, que a mantém viva, possibilitando o encontro com esses fragmentos do passado, o que permite a cada um de nós despertar o olhar para aqueles singulares momentos.

Essas imagens de família, citadas como exemplos de nossas memórias visuais, tornam-se metáfora para a compreensão da importância do papel da Fotografia na sociedade, em especial nas sociedades urbanas. São imagens que falam, que guardam algum tipo de informação no tempo e no espaço, pois como nos aponta Dantas (2011, p. 96) "toda fotografia é portadora de uma geo-história, posto que sobre elas recaem perguntas e informações que permitem ensinar sobre a época incrustrada nos espaços, o comportamento, a paisagem e o lugar", uma fonte histórico-geográfica, um texto.

No caminho de pensar "o tempo" na fotografia de cidade, nos deparamos com espaços que são verdadeiramente objetos biográficos ${ }^{2}$ da cidade, que encantam, amedrontam, uns aparentes, outros escondidos, despercebidos, que alimentam a imagem poética das ruas. São espaços de memória individuais e coletivas que evidenciam as marcas e os signos espalhados pela cidade. É Eugênia Dantas quem afirmará que “o espaço citadino visto pelo viés da imagem é um reservatório especial para religar a Geografia do passado e do presente e a fotografia é um suporte fundamental para isso" (DANTAS, 2011, p. 98), portanto, olhar a cidade requer um exercício de olhar para o tempo, de identificar narrativas escritas em seus objetos biográficos, de decifrar o que se mostra, por vezes sem nunca falar. Assim, seguimos com o pensamento proposto por Dantas (2011, p. 95) de que "a Geografia não é apenas uma ciência do presente, mas um conhecimento que dialoga com o tempo, procurando elaborar uma escrita que entende o espaço como uma inscrição material das diferentes temporalidades vivenciadas pela sociedade", tendo em vista que o espaço é ao mesmo tempo condição e reflexo do desenvolvimento dessa sociedade, o que requer de nós, professores de Geografia, uma alfabetização geográfica capaz de ajudar os sujeitos escolares a decifrar os signos presentes na cidade.

Nesta proposta, a Fotografia surge como componente de uma alfabetização geográfica para a leitura da cidade, permitindo consequentemente uma leitura do mundo, que se efetiva através do exercício de educação do olhar, do estímulo da percepção e da experiência real e imaginativa com a cidade, com seus "símbolos e emblemas que vão forjando, com a passagem do tempo, nossos sentidos de pertencimento e identidade" (MIRANDA; SIMAN, 2013, p. 16).

\footnotetext{
${ }^{2}$ Por objetos biográficos podemos entender, conforme Dantas (2011), as escolas, a prefeitura, a praça, a feira, a igreja, a rua, a casa, o sobrado.
} 
Na cidade, os objetos biográficos que a compõe participam de um movimento que amplia e aproxima os vínculos com o passado. Ela fornece, a cada um, paisagens e lugares onde as relações humanas se realizam, configurando-se num suporte espacial para a memória individual e coletiva que permite ao observador um exercício de olhar, que pode despertar uma geograficidade (DARDEL, 2011) para a cidade em suas potencialidades educativas. Percebida, observada, desenhada, fotografada, narrada, filmada, pintada ou imaginada. Somos levados a propor a leitura dessa cidade-texto, como caminho metodológico ao observar, compreender e revelar seus códigos, linguagens, enunciados e uma "pluralidade inerente às múltiplas linguagens através das quais a cidade pode ser apresentada e representada" (IDEM, p. 68).

Portanto, pensar na condição educativa da fotografia e nas possibilidades de aprendizagens presentes nela e no seu caráter elucidativo, no que se refere ao estudo da cidade, nos movimenta à compreensão de sua participação no ensino de Geografia enquanto linguagem, participante do processo de alfabetização para leitura do mundo, das imagens e através das imagens do mundo, em um exercício contínuo de educação do olhar, permitindo aos sujeitos escolares outras possibilidades de encontro com a cidade.

\section{FOTOGRAFIAS DE CIDADE EM LIVROS DIDÁTICOS}

Como a fotografia tem se feito presente nas aulas de Geografia?

A partir de uma entrevista realizada na pesquisa com professores de Geografia, foi possível deduzir que a maior parte das fotografias utilizadas pelos professores são aquelas apresentadas e disponibilizadas nos livros didáticos, não havendo espaço na maioria das vezes, para a exploração de fotografias locais enquanto possibilidade de confronto com as cidades "padrão", presentes no material didático. Assim, o livro didático é entendido como um suporte privilegiado de circulação e difusão de "fotografias educativas", visto que distribui um grande número de imagens, com alta qualidade gráfica de impressão - cores, edição, atualidade.

Porém, geralmente a fotografia é tomada enquanto auxílio visual do texto, dificilmente como uma linguagem, servindo para exemplificar, mostrar, ilustrar, apresentar um conceito, uma noção ou teoria. Assim, o uso da fotografia se resume em um tipo de prática de "comprovação" do que está escrito, como registro que apresenta provas do real. O texto didático diz 'olhem, isso é uma savana', e lá está uma imagem desta paisagem com seus 
elementos (vegetação, relevo, fauna) e pistas indicando sua equivalência ou o que está descrito em uma legenda.

Seria mesmo esse o único papel da Fotografia no livro didático?

A pesquisa realizada nestes livros, nos mostrou que o conteúdo, a estética e até mesmo as legendas das fotografias irão se apresentar ou se organizar para atender a demanda do texto escrito, como um suporte. Essa constatação nos conduz ao pensamento de que o uso indevido de uma fotografia, ou de várias delas em um livro didático, pode produzir uma espécie de generalização indevida sobre uma determinada localidade - cidade, estado, região, país, continente - criando estereótipos, reforçando o imaginário de senso comum. Essa ideia tornase ainda mais agravante quando consideramos que existe "uma construção de memória via fotografia" (OLIVEIRA JÚNIOR; SOARES, 2013, p. 202).

$\mathrm{O}$ entendimento da existência de memórias construídas a partir de fotografias, em livros didáticos, nos levaria a elaborar um novo questionamento: que imagens e/ou percursos imaginativos os alunos criam através das fotografias presentes no livro? Assim, buscou-se considerar quais imagens seriam recorrentes e como se apresentariam atreladas a práticas educativas no estudo das cidades. O que se constata sobre esta imagem da cidade, poderia soar distantes de "outras" realidades urbanas, porém ela vem padronizada a partir da noção de conflito, desigualdade, barulho, concreto, movimento, grandes avenidas, aglomeração de pessoas, ônibus, trânsito, edifícios, crime, comércio, etc. De fato, “o que aparece nos livros é a foto como uma tentativa de reproduzir o real de forma fidedigna" (OLIVEIRA JÚNIOR e SOARES, 2013, p. 204), dando margem para a interpretação de que o que nela aparece é a realidade, como se isso fosse possível, porém uma realidade atrelada às cidades de projeção global.

A imagem ${ }^{3}$ abaixo (FIGURA 1), discutida por Oliveira Júnior et al (2019) - que é bastante comum em algumas coleções de livros didáticos - poderá exemplificar o uso didático da fotografia, visto que a mesma é utilizada para dar provas da existência (e ilustrar os conceitos) da desigualdade social, da estratificação, da convivência mútua entre a pobreza e a riqueza nas grandes cidades.

\footnotetext{
${ }^{3}$ VIEIRA, Tuca. Paraisópolis. 2004. Disponível em: https://www.tucavieira.com.br/paraisopolis. Acesso em: 16 ago. 2021.
} 
Figura 01- Paraisópolis

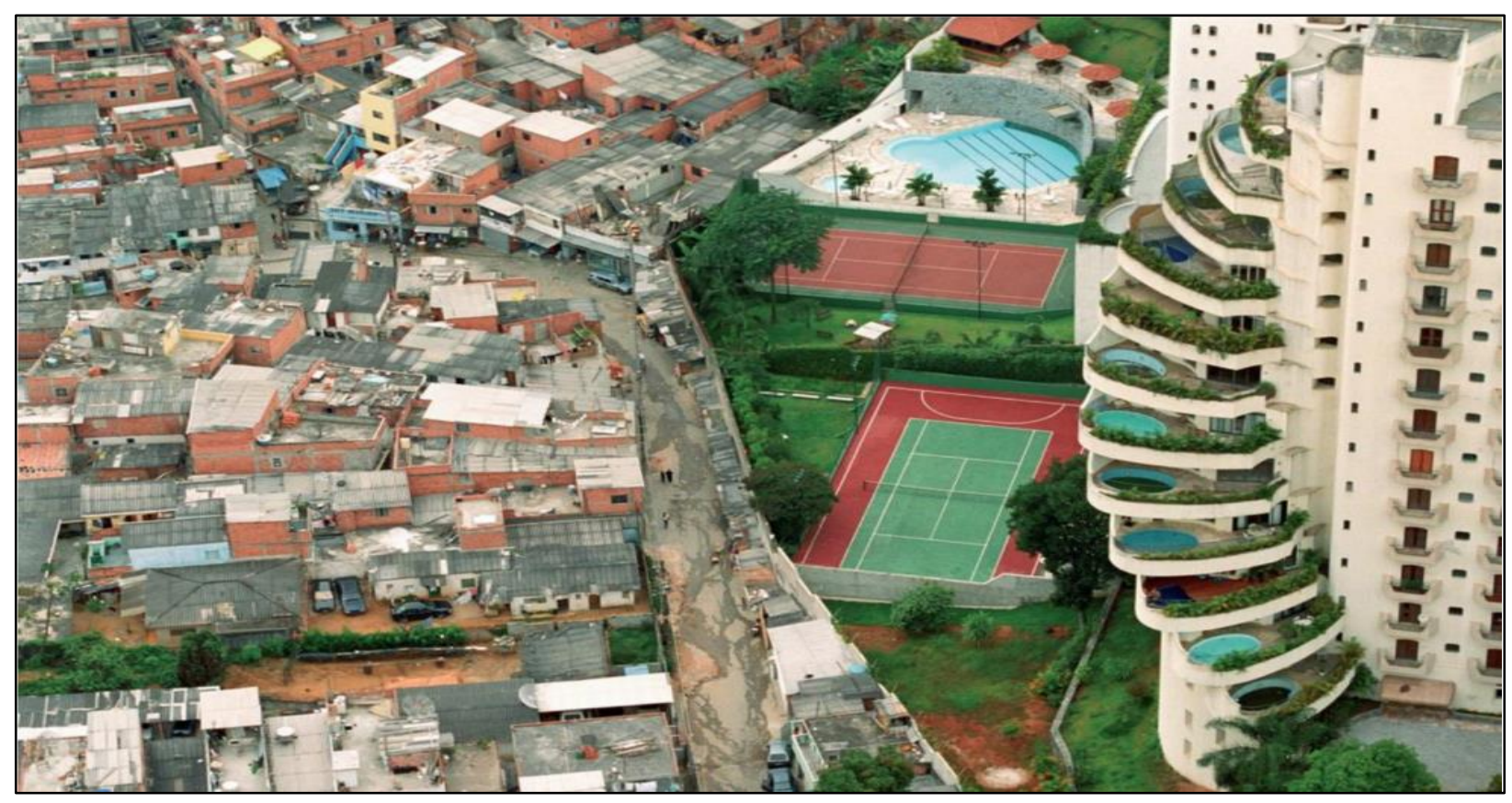

Fonte: VIEIRA, Tuca. Paraisópolis. 2004. Disponível em:

Ao passo que refletimos sobre a criação de memória através da fotografia e pensamos o conteúdo da figura 01, parece-nos que, no livro, apaga-se a ideia de criação, recriação ou representação da realidade presente na fotografia e "educam nossos olhos e memória a ver o mundo" a partir de uma única perspectiva (SOARES, 2012, p. 66). Por vezes, a fotografia didática torna-se condicionante. Os alunos olham para essas imagens e pensam, "é assim que é a desigualdade, agora eu sei/entendo". Mas seria a realidade das cidades brasileiras (e do mundo) uma única realidade? É evidente que não. Todavia, ele toma a visão como ferramenta do conhecimento e acaba por replicar uma "forma padronizada" de conceber as cidades, gerando uma falsa semelhança.

Os livros, aparentemente, tendem a esconder a linguagem presente na fotografia e a entregam como expressão da realidade. Em entrevista ${ }^{4}$ realizada no ano de 2013, concedida a Wenceslao Machado de Oliveira Júnior e Elaine do Santos Soares, o professor e autor de livros didáticos, José Eustáquio de Sene, diz que no caso dos livros de Geografia é necessário mostrar elementos do real, ou que represente uma ideia de realidade. Nessa perspectiva, a imagem vem depois do texto, o que evidencia o caráter ilustrativo atribuído a ela. Assim, se o texto traz informações sobre o aumento da população que vive e/ou mora em uma

\footnotetext{
${ }^{4}$ OLIVEIRA JÚNIOR, Wenceslao Machado de; SOARES, Elaine dos Santos. Entrevista com o Prof. Dr. José Eustáquio de Sene: Fotografias e(m) livros didáticos de geografia. Revista Brasileira de Educação em Geografia, Campinas, v. 3, n. 6, p. 192-225, dez. 2013.
} 
determinada comunidade (favela), lá estará uma fotografia para "mostrar", geralmente apresentada de cima, ou de perto, para enfatizar as situações de pobreza dessas localidades.

Sobre estes planos fotográficos, presentes em livros e materiais didáticos Soares (2012) argumenta:

Os enquadramentos mais comuns são próximos e médios e os ângulos mais comuns são frontais e de cima para baixo. Cidades mais adensadas são mostradas com enquadramento distante, amplo, com skyline, fortemente estetizadas. Cidades menos adensadas ou pobres são mostradas com enquadramento próximo, sem visão do entorno. São frontais quando mostram a pobreza de perto, escandalizada, como fotos de crianças pobres na África ou na Índia. E de cima para baixo quando mostram a pobreza de longe, nas favelas ou bairros pobres. Nas fotos de bairros pobres somente os telhados podem ser vistos. E nas fotos de favelas a ênfase é quase sempre para a ocupação de vertentes. (SOARES, 2012, p. 66)

A fotografia abaixo (FIGURA 2), presente em uma coleção de livros didáticos, ilustra a forma padronizada de dizer da cidade como espaço de desigualdades sociais e fazem parte de uma educação visual que nos ensina a "ver" os conceitos, a identificar cenários do espaço urbano, os elementos que caracterizam uma cidade, de uma maneira que não se cria questionamentos em torno dela. São comuns questões que solicitam ao aluno que: a) descrevam o cenário; b) apontem as principais diferenças ou contrastes; c) ou como no caso da imagem abaixo, caracterize o padrão de vida dos que moram nas comunidades e dos que moram nos prédios luxuosos; d) ou ainda, solicitam a criação de títulos para tais imagens. Desse modo, "o que é ou não uma cidade está relacionada à nossa educação visual, estabelecida na própria cultura imagética posta nos meios de comunicação" (IDEM, p. 2), inclusive nos livros didáticos. 
Figura 02 Favela da Rocinha e Bairro de São Conrado (RJ), 2008

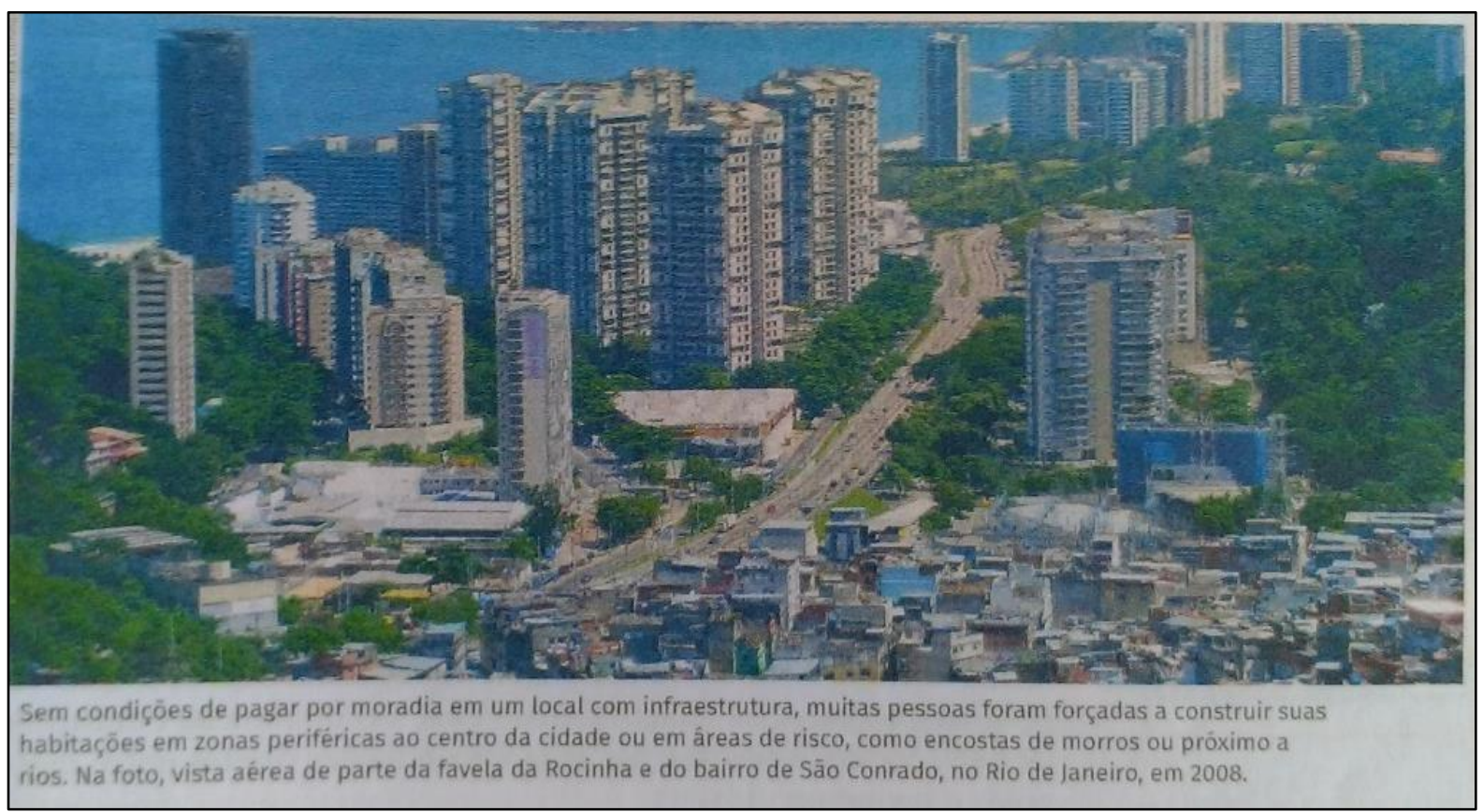

Fonte: Piccoli e Cruz, 2020.

O que apresenta essa fotografia de cidade? Qual o conteúdo presente nela? Quais objetos são priorizados ou quais tipos de situações são enfatizadas? Que leituras da cidade o aluno pode fazer a partir das fotografias e do exercício de olhar as imagens do livro didático? Essas questões nos conduzem à interpretação da Fotografia enquanto grafia do espaço, exercendo um peso significativo na formação de um imaginário de cidade nos alunos. A ruptura está em apresentar, por meio de fotografias, uma cidade que não seja, simultaneamente, repetitiva e redundante. Atenta-se ainda, ao fato de que as imagens que circulam nos livros didáticos são muito semelhantes às que estampam as veiculadas na mídia - televisão, jornal e revistas - visto que sua comercialização se dá, em grande parte, por meio de bancos de imagens, feitas, muitas das vezes, por um fotojornalista.

Não seria interessante, portanto, os alunos produzirem suas imagens de cidade, indo além da que está posta no livro didático? Pois, quando fazemos a foto, colocamos nosso olhar, nossa perspectiva. É diferente quando nos é mostrado uma fotografia que, em muitos casos, não diz da nossa realidade. Assim, o processo de criar e imaginar a cena é o que torna a proposta relevante, invertendo o processo, permitindo à imagem vir antes do texto. Permitindo a construção do conhecimento pela imagem, por intermédio da experiência.

É nesse ponto que cabe ao professor a mediação do conhecimento geográfico, sua estratégia didática e prática de ensino no estímulo do raciocínio geográfico. O que podemos 
refletir é que a imagem poderia ser mais instigante e crítica a pulsar palavras-chaves, organogramas, mapas mentais, frases e fragmentos de textos/poesias e outros elementos/recursos que venham agregar possíveis leituras de mundo que o livro pode proporcionar. Porém, quando isso não é possível apenas pela leitura da imagem, o professor deve realizar a estratégia de ensino, a partir de diferentes metodologias que provoque, promova e potencialize tais reflexões.

Um outro modo de presença de fotografias nos livros didáticos, além da ilustração de conceitos ou ideias, é a sua utilização por meio de atividades e exercícios que podem envolver a leitura, a descrição, a comparação de uma paisagem ou até a medição de um objeto, geralmente situadas em sequências didáticas. Tais sequências irão atuar também na construção de um conjunto de percepções sobre a cidade, aonde será importante que o leitor/estudante atente para os objetos pertencentes ou elementos da imagem que remetam à cidade, nos levando a refletir sobre que memórias essas fotografias produzem. Memória aqui entendida a partir de Oliveira Junior. (2019, p. 4), como as "marcas presentes em nós que preservam certas imagens e ações do esquecimento".

Estas sequências didáticas, geralmente contextualizadas na proposta de ensino presente no livro didático, indicam que tipo de atividade que poderá ser desenvolvida através da leitura dos elementos presentes em fotografias, direcionando, portanto, a forma que o estudante deve ou pode ler aquela imagem enquanto informação visual acerca de uma dada realidade, como pode-se ver na figura 3 . 
Figura 03 - Theatro Municipal de São Paulo (SP)

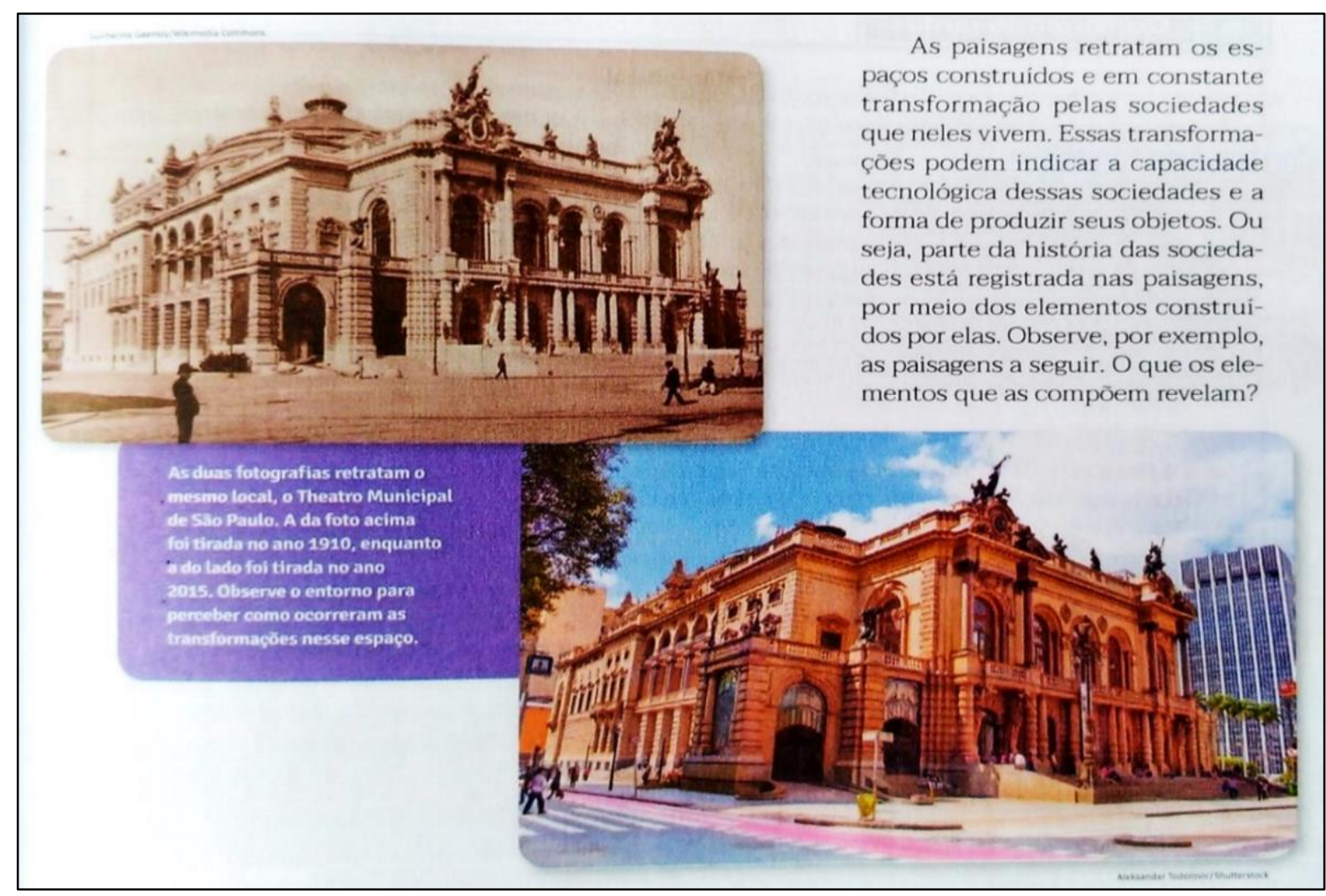

Fonte: Piccoli e Cruz, 2020.

A habilidade de comparação é bastante requerida nesse tipo de díptico fotográfico: comparação de espaços e obras públicas, de imagens "antigas" e recentes de um mesmo lugar, as diferenças entre o rural e o urbano, de uma mesma rua ou de um mesmo prédio em tempos distintos; compara-se a pobreza, a desigualdade, o processo de favelização e tantos outros aspectos das cidades. Em geral, das grandes cidades e metrópoles. Esse pequeno conjunto de imagens nos revela temporalidades e funcionalidades urbanas, em partes, alguns dos sentidos de cidade que estão em nossa memória - e na memória de muitos alunos - o que, até certo ponto, intermedia também nossa prática espacial. A partir delas, a cidade "é entendida não como algo que se manifesta fisicamente no espaço da superfície do planeta, mas também como algo que se faz nas imagens e palavras, [...] que se constitui tanto daquilo que se manifesta física e socialmente nela quanto nos discursos e falas que se dobram sobre" (OLIVEIRA JÚNIOR, 2019, p. 10).

É válido, portanto, pensar que as fotografias contribuem para nossa formação e educação visual, assim como para a educação geográfica de maneira muito ampla, atuando na criação de memórias sobre as paisagens e lugares que visitamos (ou não). Essa mesma formação e educação visual se dá para nossa produção de imagens e sentidos sobre a cidade. As imagens 
participam com menor ou maior força das memórias que temos ou criamos sobre o espaço urbano e suas paisagens, seus objetos e sentidos. Assim:

[...] as fotografias que povoam os materiais e percursos escolares possuem um objetivo bem específico: ilustrar/mostrar um determinado fato ou elemento ou fenômeno geográfico de maneira realista, de modo a amparar e auxiliar o professor a ensinar um conteúdo curricular específico. (OLIVEIRA JUNIOR, 2019, p. 3)

Outra questão que envolve as imagens nos livros didáticos está associada ao fato de muitas das vezes a fotografia de um lugar ser tomada como o lugar em si, não havendo espaço para outros percursos imaginativos acerca das paisagens daquele lugar. Com isso, é importante produzir reflexões acerca do conteúdo dessas imagens, criar interpretações, construir significados e permitir aos alunos compreender que essas imagens são fragmentos de paisagens desta ou daquela cidade. Portanto, "precisamos cuidar para não continuar a dizer aos nossos alunos que as fotografias de um lugar nos mostram a paisagem daquele lugar" (OLIVEIRA JÚNIOR, 2019. p. 9).

Por fim, é importante deixarmos claro que nossa pretensão não foi realizar uma avaliação $^{5}$ destas obras (reconhecendo o avanço técnico e qualitativo destes) mas compreender como estas imagens, em especial às de cidades, atuam nas aulas de Geografia. $\mathrm{O}$ que iremos propor a seguir é que, conhecer uma cidade, perpassa além de um movimento do pensar, mas de um questionamento sobre como este espaço é retratado, mostrado, compartilhado e inventado diariamente, diante de cada um de nós, pelas câmeras fotográficas, nos smartphones, nas telas e, principalmente, como ela participa do desenvolvimento de habilidades e competências, bem como do pensamento e do raciocínio espacial.

\section{A CIDADE EM SEQUENCIA: NOS PASSOS DE UM PROFESSOR DE GEOGRAFIA QUE FOTOGRAFA}

Gosto do caminhar porque ele é lento e desconfio que a mente, à semelhança dos pés, funciona a uns cinco quilômetros por hora.

Rebecca Solnit (2016, p.20).

\footnotetext{
5 Não iremos aprofundar a escolha dos livros neste artigo, porém esta escolha se orienta a partir do PNLD (Programa Nacional do Livro e do Material Didático) de 2020 que chegou às escolas em 2019.
} 
No momento em que vislumbramos a construção de uma metodologia para o ensino de Geografia que possibilitasse aos alunos "estudar" a cidade de um modo caminhante, dinâmico, entendíamos que esta deveria possibilitar a experimentação do espaço urbano através do reconhecimento de algumas marcas presentes na paisagem: de grupos e dinâmicas sociais, de movimento e de transformação, da passagem do tempo, da apropriação do espaço urbano pelo capital, o poder político e econômico, etc.

Desta intenção, compreendemos que para esta proposta de estudo da cidade, enfatizando Macaíba, localizada na região metropolitana de Natal, no Rio Grande do Norte, deveríamos pensar e propor possibilidades de confronto das imagens da cidade que cada estudante carregaria, dando-lhe meios de se reconhecer-se (e os outros que a habitam) neste recorte espaço-temporal. É válido que a discussão/diálogo comece na escola, todavia não sendo ela o único espaço para este confronto de ideias, cabe ao professor de Geografia desenvolver formas de levar a cidade para a aula (e vice-versa) e o aluno a reconhecer sua cidade.

Tais questões nos levam ao encontro de Lana Cavalcanti (2002) reconhecendo a necessidade de construir práticas escolares com a rua/cidade que promovam o encontro das crianças e jovens com o espaço urbano, fazendo-os reconhecer seus objetos referenciais, como suas principais ruas, o mercado público, a prefeitura, a Igreja, a barbearia, a praça ou a quadra de esportes, possibilitando ao sujeito a capacidade de fazer a leitura da paisagem urbana. Neste sentido, a leitura da paisagem apenas acontecerá de forma efetiva e eficaz quando pudermos aproximar a cidade imaginada - projetada nos livros - com a cidade existente, permitindo que o estudante reconheça a cidade (a sua cidade) como uma escrita e, como se faz com todo texto, a leia.

A partir das possibilidades indicadas pela autora sobre o estudo do "entorno", elegeuse a Fotografia como linguagem a estruturar e mover esta prática. Faz-se necessário, portanto, além de reconhecer sua existência através da paisagem e seus objetos urbanos, conhecer seu contexto - entendendo que a cidade possui dimensões de natureza histórica, geográfica, sociológica, política, antropológica e estética - e suas memórias. Recorrer ao contexto, portanto, é buscar localizar-se no tempo e no espaço da cidade, dando margem ao entendimento do espaço urbano em sua totalidade, produzido e reproduzido cotidianamente, por meio das vivências de seus habitantes.

Ao eleger a centralidade de uma sequência didática para esta pesquisa, pudemos reconhecer em algumas sequências encontradas em livros didáticos, sites e materiais de consulta, que estas se estruturam em uma dinâmica: organizada por etapas, dentro de uma 
mesma temática, aprofundando-a de forma gradativa. Tais etapas podem ser determinadas de acordo com a disponibilidade de horários do professor e varia de acordo com o tema a ser explorado. Assim, elegemos como possibilidades de experimentação da sequência: explorar, conhecer, observar, ler e o contar.

O explorar visto como o momento de realizar experiências de apropriação de alguns espaços da cidade, conduzidos pelo professor, podendo ser solicitado aos alunos que relatem, de forma narrativa e/ou visual, suas experiências investigativas e de descobertas pela cidade. É interessante que alunos e professores possam ter em mãos diários de bordo, para os registros narrativos, ideias ou questões que forem surgindo ao longo da exploração urbana.

No contexto da observação, espera-se que os alunos possam identificar elementos do seu entorno - sua casa, rua, bairro ou escola - mas que manifeste suas experiências cotidianas. Para sua realização, pode-se solicitar aos alunos que, de forma espontânea, façam observações dos espaços citados, o que pode possibilitar diálogos com os outros alunos e com o professor. Esse é o momento de uma pausa para o corpo, que pode disparar a percepção do que está ao redor "em todas as direções”. Assim, experiências ligadas à observação poderiam levar os sujeitos a decodificar o espaço que o rodeia, levando-o a criação de referenciais (de orientação, localização), aonde os movimentos de seus corpos atuariam na elaboração de signos, no reconhecimento de grafias no espaço e a identificação de lugares significantes.

A leitura, por sua vez, pode se dar através da apreciação de fotografias de paisagens urbanas, podendo o professor selecionar e/ou solicitar aos alunos que busquem por fotografias urbanas de diversas cidades do Brasil, ou de outras partes do mundo. Neste momento, é possível realizar comparações entre as imagens de cidades, em busca por reconhecer as diferenças e semelhanças entre estas, questionando o "padrão" de cidade presente em livros didáticos. Um outro caminho, poderá ser a apresentação de fotografias antigas da cidade, permitindo o confronto de imagens do passado com imagens atuais, criando dípticos fotográficos.

Já a experimentação se dará tanto pela manipulação da linguagem fotográfica ou de conceitos ligados à cidade, quanto da experimentação do caminhar pelas ruas, permitindo aos alunos construir uma forma própria de expressar-se acerca do tema e experimentar pedagogicamente o objeto de estudo. A experiência, portanto, nos permite conhecer os lugares e, na perspectiva da experiência, a cidade enquadra-se na classe de objeto e, embora não muito fácil de se manipular ou mover, é "um objeto no qual se pode morar" (TUAN, 1983, p. 14). 
Logo, quanto mais nos relacionamos com a cidade, mais criamos a partir dela. Para tanto, cabe ressaltar que só há efetivamente uma experiência com a cidade quando há lugar para o corpo se mover. Nessa etapa, o professor pode organizar oficinas fotográficas, apresentando conceitos básicos - fotografia em modo manual, planos fotográficos, luz, velocidade do obturador, ISO, diafragma, etc. - e saídas fotográficas pela cidade, permitindo aos alunos realizarem seus registros fotográficos e explorar conceitos, vistos em aula.

Por fim, o contar. Este constitui o momento de elaborar os produtos narrativos, escolher as fotografias, criar legendas, trazer à tona as histórias presente nas fotografias realizadas e promover exposições. Aqui é o lugar da narrativa, a união da linguagem visual com a linguagem escrita, momento dedicado a revelar as reflexões, ideias e experiências da proposta. Toda a proposta caminha em direção a esse momento, não pela exposição, mas pelo potencial dado ao texto e a imagem, enquanto possibilidade de dizer alguma coisa, de falar daquilo que é nosso.

Diante de nós e dessa proposta, uma realidade apresenta-se bastante clara e concreta: a paisagem urbana pode ser experienciada de várias maneiras. Tal reflexão nos permite dizer que algumas condições da cidade - outras não - encorajam as pessoas a conhece-la e a ter consciência dela a ponto de captar sua "alma" em palavras, sons, imagens. Nessa perspectiva, deve-se compreender que a experiência não é algo imediato, necessita de tempo e por isso cada vez mais rara, pois "a experiência é o que nos passa, o que nos acontece, o que nos toca. Não o que se passa, não o que acontece ou o que toca" (LARROSA, 2002, p. 21). Desse modo, ao passo que articulamos a paisagem urbana pela palavra e pela imagem, passamos a identificar, reconhecer e perceber seus objetos biográficos, lugares e paisagens.

\section{SEQUENNCIA DIDÁTICA: O CAMINHAR E O FOTOGRAFAR COMO FORMA DE CONHECER A CIDADE}

É o humor de quem a olha que dá forma à cidade de Zemrude. Quem passa assobiando, com o nariz empinado por causa do assobio, conhece-a de baixo para cima: parapeitos, cortinas ao vento, esguichos. Quem caminha com o queixo no peito, com as unhas fincadas nas palmas das mãos, cravará os olhos à altura do chão, dos córregos, das fossas, das redes de pesca, da papelada. (CALVINO, 1990, p. 64)

Esta sequência didática, teve como orientação a Base Nacional Comum Curricular (BNCC), visto que a mesma se apresenta como parte de nosso contexto educativo, tendo sido desenvolvida em vista a atender o Ensino Fundamental II, em específico às turmas de $6^{\circ}$ e $7^{\circ}$ 
ano - o que não impede sua prática em outras etapas do Ensino Básico ou em outras estruturas curriculares. A proposta de sequência está estruturada ${ }^{6}$ por meio da organização de planos de aula, de modo que as atividades e conteúdos propostos toquem no desenvolvimento de habilidades, como sugere a BNCC, para a série/turma ou modelo de currículo a que se destina a proposta.

A proposição de uma sequência contextualizada neste currículo que visa desenvolver um conjunto de habilidades e competências, sugere um movimento de pensar as questões centrais do processo educativo dos alunos - o que aprender, para que aprender - e dos professores - como ensinar, como promover aprendizagens e como avaliar o aprendizado. Porém, o que faz-se protagonista nesta pesquisa seria a utilização de diferentes linguagens que integram o corpo estrutural da BNCC, seja ela verbal, corporal, visual, sonora ou digital, além do estimulo ao contato com os conhecimentos das linguagens artísticas, matemáticas e científica, o que pode permitir ao estudante se expressar, partilhar informações, sentimentos e ideias em diferentes contextos de aprendizagem, solicitando ainda a adequação de suas proposições à realidade local destas instituições.

Ao realizar a leitura da BNCC, o tema cidade, ou melhor, o estudo do espaço urbano é contemplado desde os primeiros anos do Ensino Fundamental. O conteúdo é explorado de forma significativa a partir do $5^{\circ}$ ano do Ensino Fundamental I (anos iniciais), e contemplado em outras perspectivas de análise entre as turmas de $6^{\circ}$ e $7^{\circ}$ ano do Ensino Fundamental II (anos finais) estando presente nos livros e outros materiais didáticos, como sugere a BNCC e pode-se observe nos quadros 1,2 e 3.

Quadro 1 - Habilidades BNCC 5 ${ }^{\circ}$ ano

\begin{tabular}{|c|c|c|l|}
\hline ANO/FAIXA & $\begin{array}{c}\text { UNIDADE } \\
\text { TEMÁTICA }\end{array}$ & $\begin{array}{c}\text { OBJETOS DE } \\
\text { CONHECIMENTO }\end{array}$ & \multicolumn{1}{|c|}{ HABILIDADE } \\
\hline & & $\begin{array}{l}\text { EF05GE03: Identificar as } \\
\text { formas e funções das } \\
\text { cidades e analisar as } \\
\text { mudanças sociais } \\
\text { econômicas e ambientais } \\
\text { provocadas pelo seu } \\
\text { crescimento; }\end{array}$ \\
$5^{\circ}$ ANO & Conexões e escalas & $\begin{array}{c}\text { Território, redes e } \\
\text { urbanização } \\
\text { EF05GE04: Reconhecer as } \\
\text { características da cidade e } \\
\text { analisar as interações entre }\end{array}$ \\
\hline
\end{tabular}

\footnotetext{
${ }^{6}$ A sequência didática pode ser encontrada no trabalho completo do pesquisador, intitulado: A linguagem fotográfica no ensino de geografia: uma sequência didática para o estudo da cidade.
} 


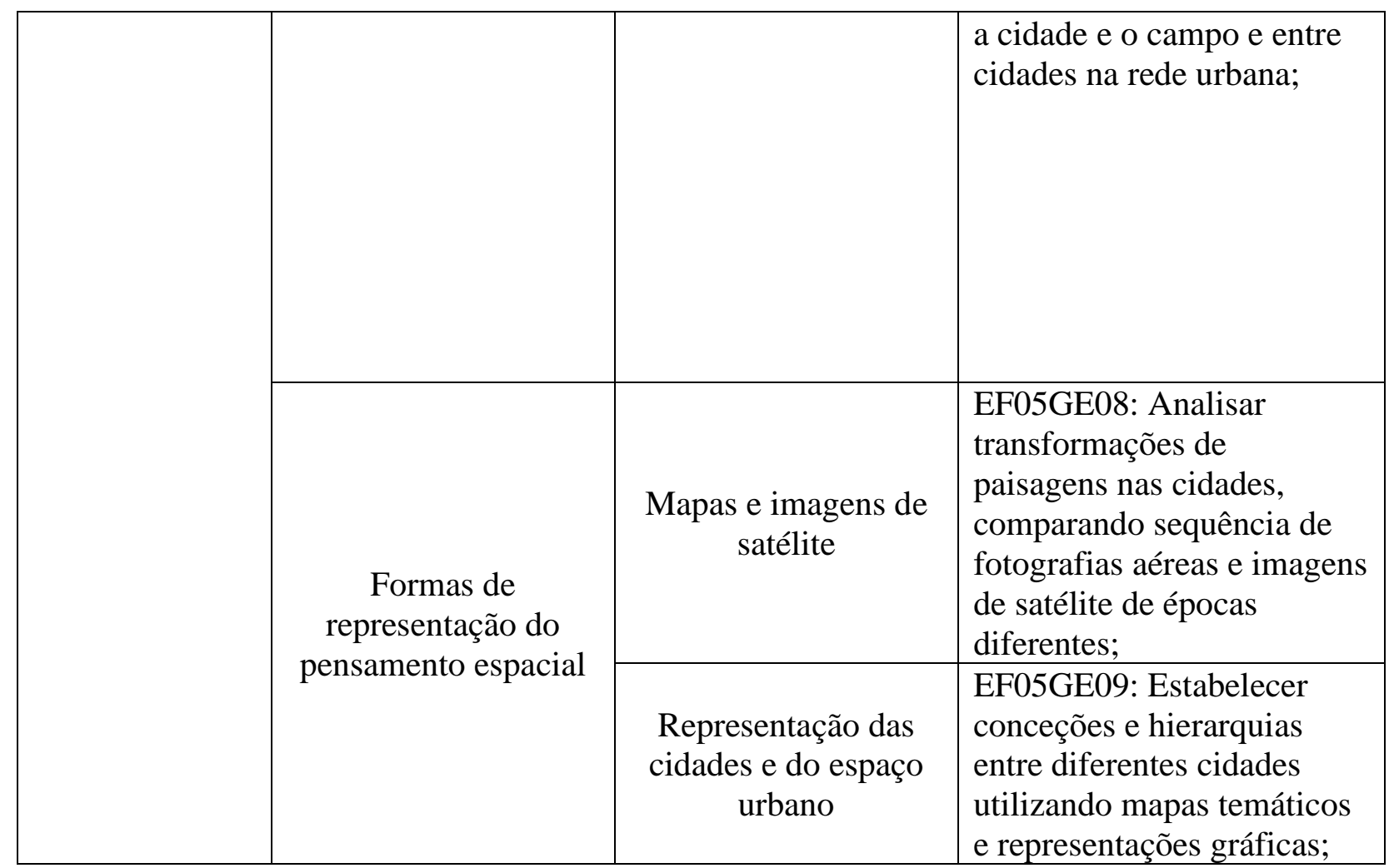

FONTE: Adaptado de Base Nacional Comum Curricular (2016, p. 379)

Quadro 2 - BNCC 6 ${ }^{\circ}$ ano

\begin{tabular}{|c|c|c|c|}
\hline ANO/FAIXA & $\begin{array}{l}\text { UNIDADE } \\
\text { TEMÁTICA }\end{array}$ & $\begin{array}{c}\text { OBJETOS DE } \\
\text { CONHECIMENTO }\end{array}$ & HABILIDADE \\
\hline \multirow{2}{*}{$6^{\circ} \mathrm{ANO}$} & $\begin{array}{c}\text { O sujeito e seu lugar } \\
\text { no mundo }\end{array}$ & $\begin{array}{c}\text { Identidade } \\
\text { sociocultural }\end{array}$ & $\begin{array}{l}\text { EF06GE01: Comparar } \\
\text { modificações das paisagens } \\
\text { nos lugares de vivência e os } \\
\text { usos desses lugares em } \\
\text { diferentes tempos; } \\
\text { EF06GE02: Analisar } \\
\text { modificações de paisagens } \\
\text { por diferentes tipos de } \\
\text { sociedade, com destaque } \\
\text { para os povos originários; }\end{array}$ \\
\hline & Mundo do trabalho & $\begin{array}{c}\text { Transformações das } \\
\text { paisagens naturais e } \\
\text { antrópicas }\end{array}$ & $\begin{array}{l}\text { EF06GE06: Identificar as } \\
\text { características das paisagens } \\
\text { transformadas pelo trabalho } \\
\text { humano e a partir do } \\
\text { desenvolvimento da } \\
\text { agropecuária e do processo } \\
\text { de industrialização; } \\
\text { EF06GE07: Explicar as } \\
\text { mudanças na interação } \\
\text { humana com a natureza a }\end{array}$ \\
\hline
\end{tabular}




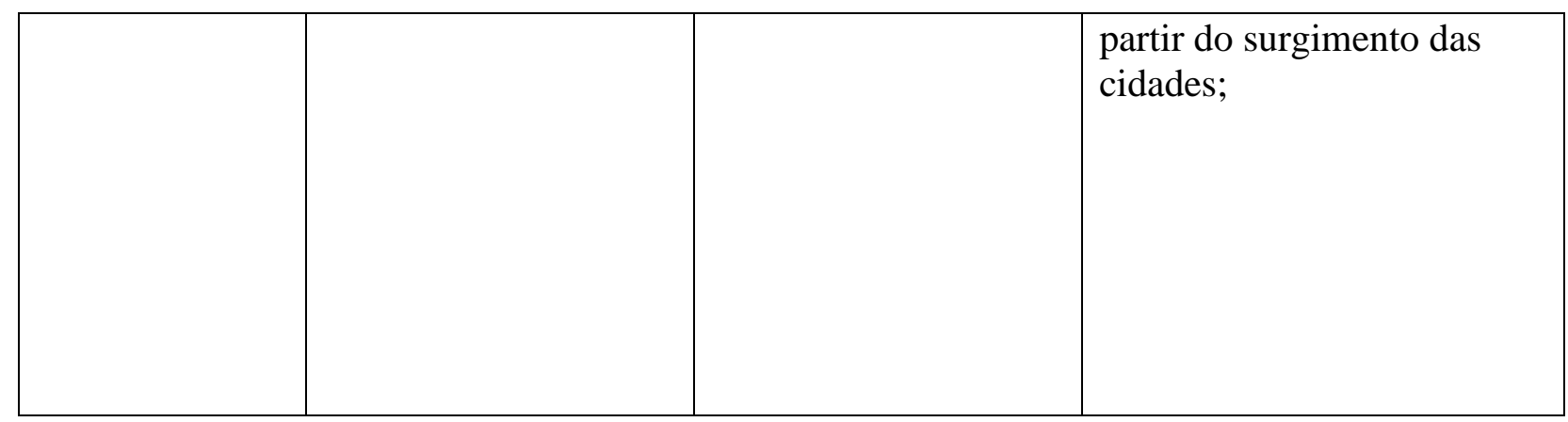

FONTE: Adaptado de Base Nacional Comum Curricular (2016, p. 385)

Quadro 3 - BNCC $7^{\circ}$ ano

\begin{tabular}{|c|c|c|l|}
\hline ANO/FAIXA & $\begin{array}{c}\text { UNIDADE } \\
\text { TEMÁTICA }\end{array}$ & $\begin{array}{c}\text { OBJETOS DE } \\
\text { CONHECIMENTO }\end{array}$ & HABILIDADE \\
\hline $7^{\circ}$ ANO & Mundo do trabalho & $\begin{array}{l}\text { Desigualdade social e } \\
\text { trabalho }\end{array}$ & $\begin{array}{l}\text { EF07GE08: Estabelecer } \\
\text { relações entre os processos } \\
\text { de industrialização e } \\
\text { inovação tecnológica com } \\
\text { as transformações } \\
\text { socioeconômicas do } \\
\text { território brasileiro; }\end{array}$ \\
\hline
\end{tabular}

FONTE: Adaptado de Base Nacional Comum Curricular (2016, p. 387)

A partir desta leitura do currículo, é possível perceber que o trabalho com as habilidades pode conduzir a um estudo progressivo do tema cidade, num trabalho constante com o desenvolvimento do raciocínio geográfico, permitindo o exercício do pensamento espacial por meio do contato com a linguagem fotográfica, o que diversifica o trabalho com as linguagens e amplia as possibilidades de leitura de mundo.

Embora a maioria das habilidades que abordam a questão da cidade se encontre no $5^{\circ}$ ano do Ensino Fundamental I, existem habilidades, principalmente no $6^{\circ}$ ano do Ensino Fundamental II, que falam dos lugares de vivência e nos permitem articular e resgatar as habilidades presentes no $5^{\circ}$ ano, contribuindo para um aprofundamento conceitual da sequência proposta. Desse modo, o desenvolvimento dessas habilidades por meio da linguagem fotográfica poderia potencializar formas de aprendizagem, estimular a curiosidade, provocar uma mudança de olhares de modo que os sujeitos deem sentido a suas práticas espaciais, tomando a fotografia e a Geografia escolar como estratégia de produzir conhecimentos e dissolver verdades.

Como apresentado em outros trechos, Macaíba/RN (FIGURA 4) foi nosso espaço de prática e experimentação, o que indica que outros professores a adaptem e a construam de acordo com seu contexto, com suas possibilidades de atuação, horários, turmas ou grupo de 
alunos. Esta sequência é uma montagem, no sentido de aceitar outras formas de organização e arranjos, o que permite sua utilização em vários cenários e contextos urbanos, tal qual seu desmembramento e adaptação.

Figura 04 - O percurso no contexto de Macaíba e da Região Metropolitana de Natal/RN

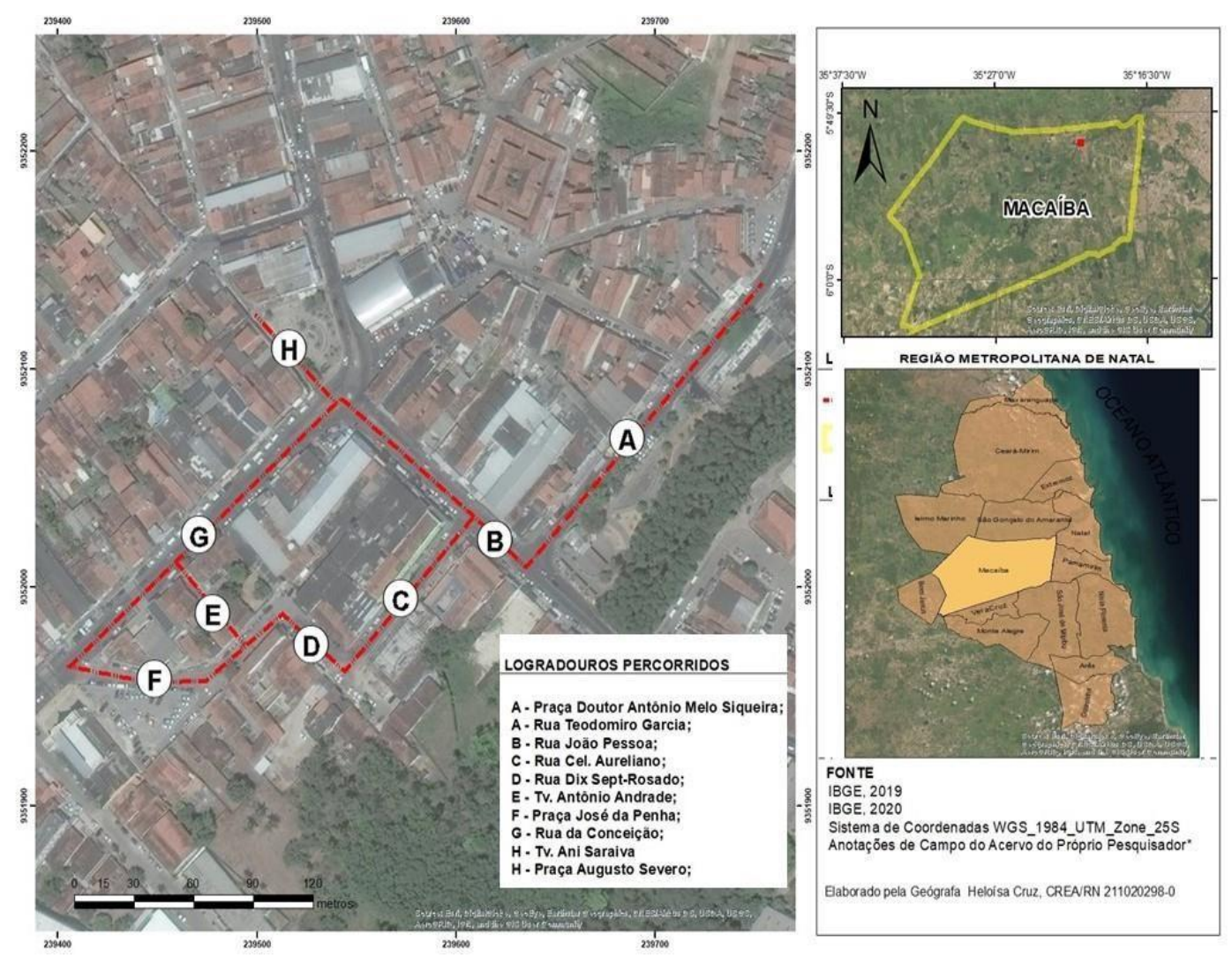

Fonte: Nascimento, 2021.

Durante as saídas fotográficas na cidade de Macaíba, pensávamos em como uma sequência didática poderia se efetivar no campo da experiência, ao mesmo tempo que nos indagávamos sobre o que isso significava dentro de um processo de ensinar e, mais ainda, de ensinar e aprender Geografia. Assim, o mapa de itinerário apresentado acima (FIGURA 4), indica o que foi o recorte da pesquisa, delimitado como "centro" da cidade de Macaíba/RN. Ao explorar tal percurso fora possível experimentar, a partir do caminhar, diversos cenários. A exemplo dos pontos A e B, que permitiu ao pesquisador se deparar com uma paisagem dicotômica: de um lado uma vegetação de mangue, enquanto do outro uma rua comercial, reproduzindo uma relação natureza x sociedade. São estes cenários/recortes diversos que pluralizam e potencializam esta prática pautada na experiência e vivência dos sujeitos escolares com seus lugares de vivência, como sugere a habilidade EF06GE01, paras turmas de $6^{\circ}$ ano. 
Neste momento, foi de grande valia, o encontro com o trabalho de Rosa e Silva (2020), que desenvolve uma proposta de cartografia experiencial com alunos da cidade de Florianópolis/SC, na qual utiliza uma caminhada em deriva, sem percurso preestabelecido. Considerando esta como um modo de se deslocar diferente daqueles presentes em trabalhos de campo (ou estudos do meio) nas disciplinas de Geografia, "onde o professor direciona e delimita o olhar para alguns pontos pré-estabelecidos de interesse, e relevantes ao conteúdo programático" (SILVA, 2020, p. 94).

Esta proposta de sequência deveria também expressar um incomodo em relação à forma como a cidade é apresentada massificada, homogênea, repetitiva e assim, "sem alma". Para isso, é necessário educar os olhos (os sentidos), mas também os passos daqueles que caminham, e retomar as ruas, retroceder. Ainda que, olhar para todas as direções requeira de nós um esforço físico para a produção de experiências, o caminhar não será apenas um exercício de deslocamento no espaço, mas também um exercício para os sentidos, “é isso que tornar o caminhar ambíguo e infinitamente fértil: é tanto um meio quanto um fim, trajeto e destino" (SOLNIT, 2016, p. 24).

A versão final da Sequência Didática integra a dissertação final, momento em que se definiu um trajeto na cidade de Macaíba-RN, entendido como um percurso educativo com orientações do que "poderia" ser fotografado pelos alunos, um roteiro de investigação geográfico e fotográfico, inspirado nos trabalhos de campo situacionistas, de deriva. Algumas sugestões do que pode ser feito na atividade com turmas podem ser lidas logo abaixo.

a) Antecipadamente, solicite aos alunos que para realização da atividade é interessante eles estarem com seus smartphones; professor, se for possível, leve uma câmera fotográfica para que os alunos possam, também, entender seu funcionamento, cabendo a você, conhecer o mínimo dos conceitos essenciais que envolvem uma câmera DSLR;

b) Organize sistematicamente o itinerário a ser percorrido durante a realização da atividade;

c) Tenha em mãos um mapa da cidade, no qual seja possível aos alunos visualizarem o trajeto a ser percorrido;

d) Reúna o grupo de alunos e passe as orientações gerais e específicas da atividade: o que irão fazer, como farão, o que será necessário;

e) No início da atividade solicite aos alunos que façam fotografias panorâmica da cidade, que escolham elementos históricos, atentem para a arquitetura urbana como prédios antigos ou novos, que busquem pelos detalhes da paisagem citadina;

f) Converse, previamente, com os alunos sobre os elementos que compõem uma paisagem natural (rios, árvores, relevo...) e culturais (manifestações artísticas, poéticas, arquitetônicas, entre outras);

g) Ter em mãos, se possível, imagens antigas de locais atuais, permitindo um momento de comparação e releitura fotográfica; 
h) Durante o percurso, organize momentos de parada e em grupo para realização das fotografias, solicitando aos alunos que fotografem a mesma paisagem (objetos biográficos da cidade) e comparem seus resultados fotográficos;

i) É importante ter me mente a forma de exposição dos registros produzidos pelos alunos, podendo ocorrer: no pátio da escola para apreciação de outras turmas; em um blog que conte de forma narrativa e visual os registros; ou ainda apresentada nas redes sociais;

j) É indispensável que os alunos além das fotografias, tenham tempo para produzir legendas e contar sobre sua(s) foto(s);

Para realização deste experimento, o pesquisador se colocou enquanto sujeito escolar, como aquele que experimenta a cidade e fotografa ${ }^{7}$. No itinerário produzido, um conjunto de ruas foram escolhidas para o experimento visual e fotográfico. A experiência e o contato do pesquisador com a cidade, permitiu a tentativa de ilustrar o que os alunos, ao realizarem o mesmo percurso, poderiam se deparar e vir a fotografar dentro da cidade, por meio do itinerário. As imagens contam da arquitetura, das marcas do tempo, falam da natureza, dizem do sagrado, evidenciam a relação dos sujeitos - artistas ou não - com o espaço citadino. São detalhes, recortes da natureza, do movimento típico da cidade, da feira e dos signos em paredes ou placas de trânsito que contam um pouco do trajeto caminhante do pesquisador.

Um dos ensaios temáticos, foi intitulado de "Cenas urbanas" (FIGURA 5 E FIGURA 6) e se deu a partir de registros livres de um caminhar pela cidade, e permitiram revelar um modo de perceber a cidade dos sujeitos escolares, podendo se tornar um material qualitativo sobre as experiências, preferências, afetos e pertencimentos destes alunos na cidade. É a forma como se percebe seu espaço enquanto sujeito daquela paisagem. Não fora intencional mostrar cenas de uma cidade vazia, é apenas um reflexo da pandemia provocada pela Covid19 que, de certo modo, contribuiu para a ausência de pessoas na maioria das imagens desta série.

\footnotetext{
${ }^{7}$ A pandemia provocada pelo vírus da Covid-19 impossibilitou a realização desta atividade com alunos regulares da escola básica de $6^{\circ}$ e $7^{\circ}$ ano do município de Macaíba/RN, o que me levou, tomando todos os cuidados necessários, a experimentar o itinerário produzido e fazer as fotografias que compõem essa sequência didática.
} 


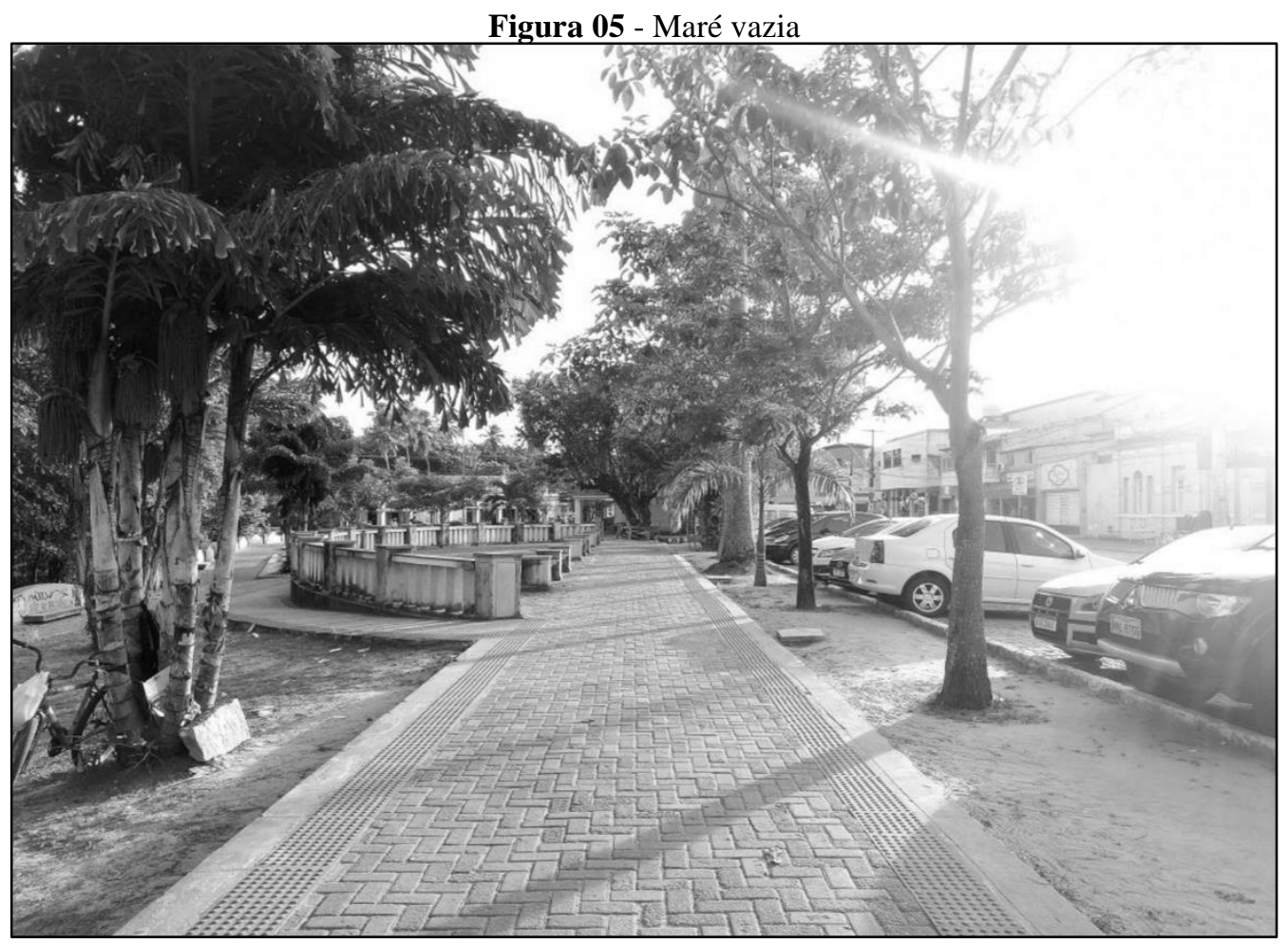

Fonte: acervo do autor, 2021.

Neste artigo, as fotografias da cidade de Macaíba, mostram apenas uma forma de ver a cidade, porém, a sala de aula permite o encontro da multiplicidade: de olhares, de engajamentos, de imaginações. Assim, a partir dessa "picada" do olhar é possível identificar e reconhecer a existência de várias cidades dentro de Macaíba/RN - ou de qualquer outra que essa proposta seja feita. 


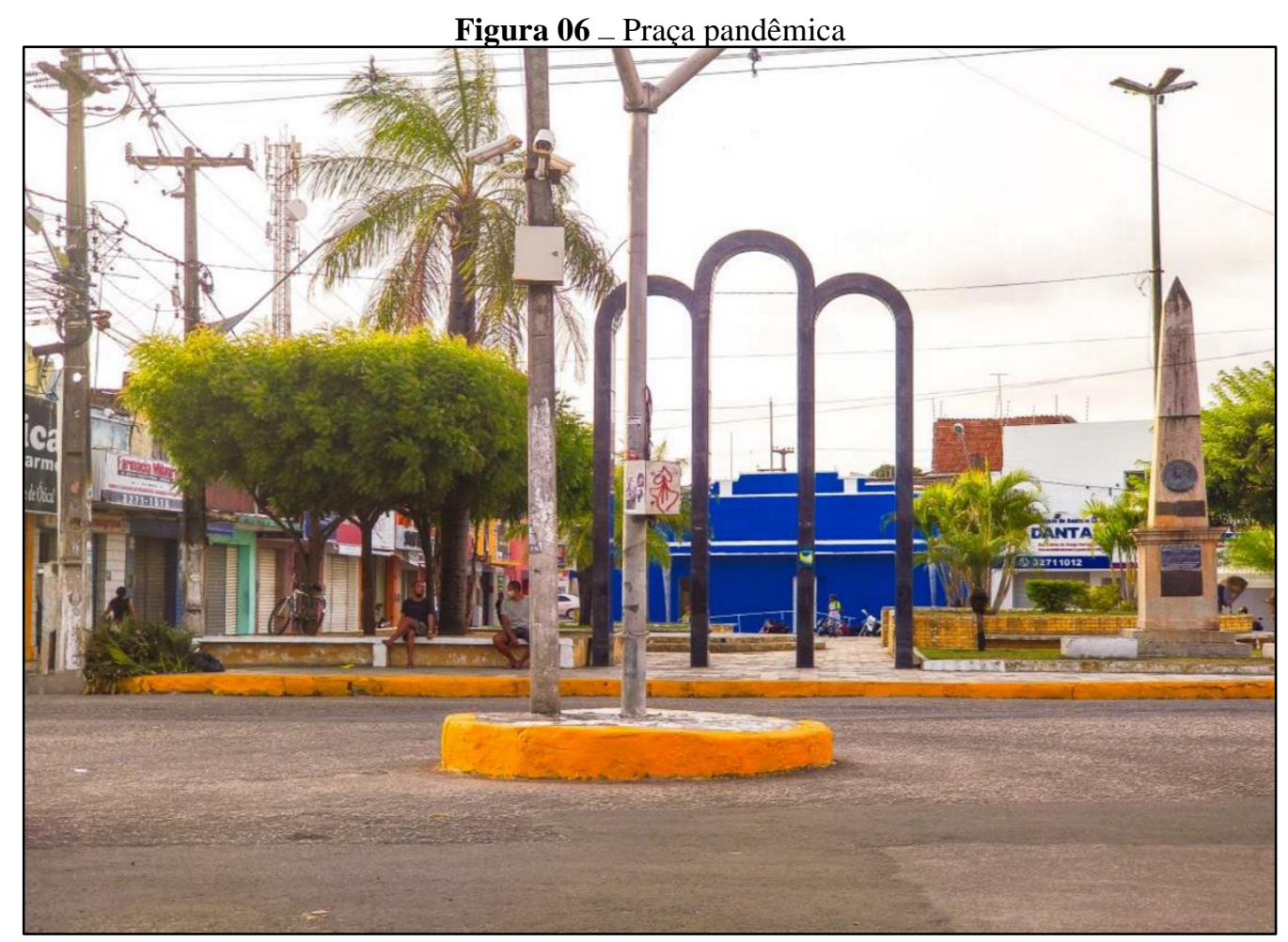

Fonte: acervo do autor, 2021.

\section{CONSIDERAÇÕES FINAIS}

Organizar e sistematizar analiticamente este conjunto de fotografias é considerado como um exercício de pensar, também, a sequência didática e o espaço geográfico como um tipo de recorte apresentado pela Fotografia. Desse modo, a sequência didática, a cidade e as fotografias se confundem, tornando-se um caminho repleto de intersecções a partir do momento em que busca compreender a experiência geográfica da cidade, onde, o corpo em movimento, torna-se capaz de perceber a paisagem por meio de múltiplos olhares e diferentes pontos de vista.

Olhar a cidade a partir do punctum e do studium, de Roland Barthes, é olhar a cidade a partir daquilo que nos toca, nos prende, nos atinge, permitindo o deslocamento por várias paisagens e lugares da cidade de Macaíba/RN. Esse deslocar do corpo e, consequentemente do olho e de outros sentidos, possibilitou transitar por inúmeras formas de enxergar essa cidade. Entende-se a partir disso, que não há uma única forma de ler, experimentar ou perceber a cidade, mas várias formas a partir de ser e estar neste espaço. Nessa experiência caminhante-fotografante, foi possível confirmar uma das ideias levantadas durante toda esta pesquisa: a cidade proporciona inúmeras formas de leitura, existindo para cada sujeito que a 
observa, de maneiras diferentes. O que revela uma experiência do sujeito com a fotografia enquanto experiência do olhar.

Pensar a cidade como espaço educativo para ensinar Geografia é, portanto, reconhecer outras formas de aprender, mas também de viver e perceber a cidade. A linguagem fotográfica, motor desse processo, move a tomada do olhar como componente essencial para experimentar o espaço urbano. São recortes e fragmentos de uma cidade que aparece descrita por meio das imagens, que recriam e grafam a experiência do olhar e dos passos em uma cartografia que é construída a cada itinerário.

\section{REFERÊNCIAS}

BARTHES, Roland. A câmara clara: nota sobre a fotografia. Rio de Janeiro: Nova Fronteira, 1984.

BRASIL. Brasil. Ministério da Educação. PNLD. Disponível em: <http://portal.mec.gov.br/busca-geral/318-programas-e-acoes1921564125/pnld439702797/12391-pnld >. Acesso em: 05 ago. 2020.

BRASIL. Ministério da Educação. Base Nacional Comum Curricular. Brasília, 2016.

CALVINO, Ítalo. As cidades invisíveis. São Paulo: Companhia das Letras, 1990.

CAVALCANTI, Lana de Souza. Geografia e práticas de ensino. Goiânia: Alternativa, 2002.

CAZETTA, Valéria e OLIVEIRA JR., Wenceslao Machado de (orgs.). Grafias do Espaço: imagens da educação geográfica contemporânea. São Paulo: Alínea, 2013.

DANTAS, Eugênia Maria. Geografizar a cidade olhando fotografias. Espaço Aberto, Rio de Janeiro, v. 1, n. 2, p.91-100, 24 set. 2011. Disponível em: <https://revistas.ufrj.br/index.php/EspacoAberto/article/view/2059/1826>. Acesso em: 20 jan. 2018.

DARDEL Eric. O Homem e a Terra: natureza da realidade geográfica. Perspectiva. São Paulo, 2015.

FERNANDEZ, Pablo Sebastian Moreira. Narrativas urbanas de um caminhante. 2008. 157 f. Dissertação (Mestrado) - Curso de Faculdade de Educação, Universidade Estadual de Campinas, Campinas, 2008.

HILLMAN, James. Cidade e Alma. São Paulo: Studio Nobel, 1993.

LARROSA, Jorge Bondía. Notas sobre a experiência e o saber da experiência. Revista Brasileira de Educação, Rio de Janeiro, v. 19, n. 19, p. 20-28, jan. 2002. Tradução de João Wanderley Geraldi. Disponível em: 〈http://www.scielo.br/pdf/rbedu/n19/n19a02.pdf $>$. Acesso em: 09 mar. 2018. 
MIRANDA, Sonia Regina; SIMAN, Lana Mara Castro (Org.). Cidade, Memória e Educação. Juiz de Fora: Editora UFJF, 2013.

OLIVEIRA JÚNIOR, Wenceslao Machado de. Fotografias, geografias e escola. Signos Geográficos: Boletim NEPEG de Ensino de Geografia, Goiânia, v. 1, p. 1-15, nov. 2019. Disponível em: 〈www.revistas.ufg.br/signos > Acesso em: 13 jan. 2020.

OLIVEIRA JÚNIOR, Wenceslao Machado de; SOARES, Elaine dos Santos. Entrevista com o Prof. Dr. José Eustáquio de Sene: Fotografias e(m) livros didáticos de geografia. Revista Brasileira de Educação em Geografia, Campinas, v. 3, n. 6, p. 192-225, dez. 2013.

OLIVEIRA JÚNIOR, Wenceslao Machado de; SOARES, Elaine dos Santos. Entrevista com o Prof. Dr. José Eustáquio de Sene: Fotografias e(m) livros didáticos de geografia. Revista Brasileira de Educação em Geografia, Campinas, v. 3, n. 6, p. 192-225, dez. 2013.

PICCOLI, Ana Paula; CRUZ, Isabela. Geografia $6^{\circ}$ ano. 2. Ed. Fortaleza, 2020.

PICCOLI, Ana Paula; CRUZ, Isabela. Geografia $7^{\circ}$ ano. 2. Ed. Fortaleza, 2020.

SILVA, Marina Coelho Rosa. O Caminhar como forma de produzir Cartografias: outras imagens do centro de Florianópolis. Dissertação (Mestrado em Educação), Universidade Estadual de Santa Catarina, Florianópolis, 2021.

SOARES, Elaine dos Santos. Devires imaginativos de fotografias didáticas. 2012. $162 \mathrm{f}$. TCC (Graduação) - Curso de Geografia, Departamento de Geografia, Universidade Estadual de Campinas, Campinas, 2012.

SOLNIT, Rebecca. A história do caminhar. São Paulo: Martins Fontes - Selo Martins, 2016. Tradução de Maria do Carmo Zanini.

TUAN, Yi-fu. Espaço e Lugar: A perspectiva da experiência. São Paulo: DIFEL, 1983. Tradução de Lívia de Oliveira.

VIEIRA, Tuca. Paraisópolis. 2004. https://www.tucavieira.com.br/paraisopolis. Acesso em: 16 ago. 2021.

Artigo recebido em: 05 de julho de 2021.

Artigo aceito em: 26 de agosto de 2021. Artigo publicado em: 13 de setembro de 2021. 